\title{
Palygorskite Supported AuPd Alloy Nanoparticles as Efficient Nano-Catalysts for the Reduction of Nitroarenes and Dyes at Room Temperature
}

\author{
Jun Xu, Shengli Guo, Lei Jia * and Wensheng Zhang \\ College of Chemistry and Chemical Engineering, Henan Polytechnic University, Jiaozuo 454000, China; \\ xjj1@hpu.edu.cn (J.X.); guoshenglihpu@163.com (S.G.); zhangwenshenghpu@163.com (W.Z.) \\ * Correspondence: jlxj@hpu.edu.cn; Tel.: +86-391-398-7816
}

Received: 17 October 2018; Accepted: 30 November 2018; Published: 3 December 2018

\begin{abstract}
In this work, AuPd alloy palygorskite based Pal- $\mathrm{NH}_{2} @ \mathrm{AuPd}$ nano-catalysts were prepared and used as catalysts for the reduction of nitroarenes and dyes at room temperature. The surface of palygorskite (Pal) was first modified with 3-aminpropyltriethoxysilane, and then covered with AuPd alloy nanoparticles through co-reduction of $\mathrm{HAuCl}_{4}$ and $\mathrm{K}_{2} \mathrm{PdCl}_{4}$. The morphology and structures of the Pal- $\mathrm{NH}_{2} @ \mathrm{AuPd}$ nano-catalysts were characterized by X-ray diffraction (XRD), energy-dispersive X-ray spectroscopy (EDS) and transmission electron microscopy (TEM). The as-synthesized Pal- $\mathrm{NH}_{2} @ \mathrm{AuPd}$ nano-catalysts displayed excellent catalytic performance in reducing 4-nitrophenol (4-NP) and various other nitroaromatic compounds. Moreover, the catalytic activities of the Pal- $\mathrm{NH}_{2} @ \mathrm{AuPd}$ nano-catalysts were adjustable via changing the atomic ratio of AuPd alloy nanoparticles, leading to the $\mathrm{Pal}-\mathrm{NH}_{2} @ \mathrm{Au}_{48} \mathrm{Pd}_{52}$ component as having the best atomic ratio. The Pal- $\mathrm{NH}_{2} @ \mathrm{Au}_{48} \mathrm{Pd}_{52}$ continued to display good catalytic stability after being reused for several cycles and there were no obvious changes, either of the morphology or the particle size distribution of the nano-catalysts. Furthermore, these $\mathrm{Pal}-\mathrm{NH}_{2} @ \mathrm{Au}_{48} \mathrm{Pd}_{52}$ nano-catalysts also provided a convenient and accessible way for the degradation of dyes in artificial industrial wastewater.
\end{abstract}

Keywords: palygorskite; AuPd alloy; nitroarenes; artificial wastewater

\section{Introduction}

Nitrobenzene has become extremely widespread in the environment due to the industrial use in the production of dyes, pharmaceuticals, pesticides and explosives [1]. As a hazardous organic compound, nitrobenzene released to the environment can irreversibly damage the health of human and animals [2]. Researchers have reported that the reduction of nitro compounds to amines compounds is highly desirable because organic amines are notable intermediates for many industrial processes, such as in the production of antipyretic drugs, dyes and polymers [3]. Many different methods have been used for the reduction of nitrobenzene or 4-nitrophenol (4-NP) to 4-AP but catalytic reduction of nitrophenol is one the simplest and most environmentally friendly methods using noble metal nanoparticles (NPs). There are many reports about metallic nanoparticles, such as Ag [4], Au [5], $\mathrm{Pd}$ [6], Pt [7], and Rh [8], used as catalysts for the reduction reactions.

In recent years, the development of noble metal particles with controlled shapes and sizes has been pursued for attaining desirable catalytic properties $[9,10]$. In the past decade, noble metal NPs have attracted considerable attention due to their unique physical and chemical properties [11-16]. Marco Filice et al. reported heterogeneous enzyme-Pd nanoparticle biohybrids with high catalytic performance in $\mathrm{C}-\mathrm{C}$ bond formation and tandem catalysis [11]. Le et al. noted that Pd NP supported on nano-silica was utilized for the catalytic reduction of 4-NP [17]. Wang et al. used MOF (metal organic 
framework) decorated with Pd NP as a catalyst, which showed great catalytic activity for the reduction of 4-NP at room temperature [18]. Bimetallic nanomaterials have recently attracted significant attention due to theoretical and potential applications as a new class of efficient catalysts [19]. In fact, bimetallic nanoparticles have been studied for many applications because their synergistic optical, electronic and catalytic advantages are clearly different from those of their parent metals [19,20]. Palladium-based alloy nanoparticles have been used as catalysts for reactions such as glycerol oxidation [21], CO oxidation [22], and nitroarenes reduction [23]. For example, Shota et al. reported that Pd-Ag alloy NPs had a higher activity for selective oxidation of glycerol to dihydroxyacetone [21]. Hosseini's group prepared PdCo alloy NPs well-dispersed on polypropylenimine dendrimer-grafted graphene, which can act as a highly efficient catalyst for direct formic acid fuel cells [24]. Other alloy catalysts, such as AuPd alloy, also displayed various catalytic or sensing activities [25-28]. However, noble metal NPs can easily aggregate due to their high specific surface energy, and their high cost and difficult removal from the reaction media also limit their large-scale applications.

Palygorskite (formula $\mathrm{Si}_{8} \mathrm{O}_{20} \mathrm{Mg}_{5}(\mathrm{Al})(\mathrm{OH})_{2}\left(\mathrm{H}_{2} \mathrm{O}\right)_{4} \cdot 4 \mathrm{H}_{2} \mathrm{O}$ ) is a kind of natural hydrous magnesium-aluminum silicate non-metallic mineral with a special one-dimensional fibrous morphology [29]. Great attention has been paid to the utilization of palygorskite, such as in adsorbents, adhesives, catalysts, and catalyst supports, due to its low-cost, eco-friendliness, unique structure and considerable textual properties [30]. It has a large surface area exhibiting excellent activity. Therefore, palygorskite ( $\mathrm{Pal}$ ) is a good choice as a catalyst support. Wang et al. [24] prepared $\mathrm{Pd}-\mathrm{Cu} / \mathrm{Pal}$ catalysts by an ammonia evaporation method and found that the composite exhibited excellent activity and stability in $\mathrm{CO}$ oxidation at room temperature. Liu et al. [29] obtained $\mathrm{Pal} / \mathrm{Fe}-\mathrm{Ni}$ via a liquid-phase reduction method and investigated its degradation of 2,2',4,4'-tetrabromodiphenylether.

To accomplish the above, in this study we report a simple way to modify Pal with 3-aminopropyltriethoxysilane in toluene and the formation of Au-Pd bimetallic alloy on $\mathrm{Pal}_{-} \mathrm{NH}_{2}$. By varying the feeding amounts of $\mathrm{K}_{2} \mathrm{PdCl}_{4}$, fine control was obtained over the synthesis of the $\mathrm{Au}-\mathrm{Pd}$ bimetallic alloy supported on $\mathrm{Pal}-\mathrm{NH}_{2}$. To investigate the correlations between the nanostructure of the bimetallic and the synergistic effects of the $\mathrm{Au}$ and $\mathrm{Pd}$, we produced the $\mathrm{Pal}-\mathrm{NH}_{2} @ \mathrm{AuPd}$ as a catalyst in the reduction of 4-nitrophenol (4-NP). The as-synthesized Pal- $\mathrm{NH}_{2} @ \mathrm{AuPd}$ nano-catalysts with atomic ratio of $\mathrm{Au}$ and $\mathrm{Pd}$ 48:52 exhibited superior activity compared with other $\mathrm{Pal}-\mathrm{NH}_{2} @ \mathrm{AuPd}$ nano-catalysts, monometallic Pal- $\mathrm{NH}_{2} @ \mathrm{Au}$ and $\mathrm{Pal}-\mathrm{NH}_{2} @ \mathrm{Pd}$, owing to the synergistic effect between $\mathrm{Au}$ and $\mathrm{Pd}$. More importantly, the Pal- $\mathrm{NH}_{2} @ \mathrm{AuPd}$ nanorods displayed excellent activity and chemical stability for long-term catalytic reactions, indicating the $\mathrm{Pal}-\mathrm{NH}_{2} @ \mathrm{AuPd}$ as a potential effective catalyst. Furthermore, the nano-catalysts reported here also indicated good wastewater treatment ability under alkaline and high salinity conditions. The study presented here provided an impetus for the application of Pal-based composite material in redox catalysis.

\section{Materials and Methods}

\subsection{Materials and Reagents}

Palygorskite was purchased from Jiangsu Autobang Corporation (Huaian, China). Potassium tetrachloropalladate $\left(\mathrm{K}_{2} \mathrm{PdCl}_{4}\right)$, hydrogen tetrachloroaurate $\left(\mathrm{HAuCl}_{4}\right)$ starch, sucrose, Congo red $(\mathrm{CR})$, reactive red (RR), acetic acid, sulphuric acid, sodium hydroxide, sodium carbonate, sodium chloride and sodium dodecyl sulphate were obtained from Sinopharm Chemistry Reagent Co., Ltd. (Beijing, China). 3-aminpropyltriethoxysilane, 4-nitrophenol, p-nitroaniline, m-nitroaniline, o-Nitroaniline (o-NA), 2,4-Nitroaniline, and sodium hydroxide $\left(\mathrm{NaBH}_{4}\right)$ were bought from Sigma Aldrich (Burlington, NJ, USA). All chemicals were of chemical reagent grade and used without any further purification. Ultrapure water was prepared by using NANO Pure Infinity System (Barnstead/Thermolyne Corp., Dubuque, IA, USA) and was used throughout all the experimental processes. 


\subsection{Preparation of $\mathrm{Pal}-\mathrm{NH}_{2}$}

In order to introduce terminal amino groups onto the palygorskite surface [31], $500 \mathrm{mg}$ of palygorskite was dispersed into $60 \mathrm{~mL}$ toluene with ultrasound for $10 \mathrm{~min}$ and then $1 \mathrm{~mL}$ of 3-aminopropyltrimethoxysilane was added dropwise to the above mixture with vigorous stirring. After the mixture was reacted for $8 \mathrm{~h}$ at temperatures of $90^{\circ} \mathrm{C}$, the solution was continuously stirred for another $1 \mathrm{~h}$ at room temperature. The final solution was centrifuged at $5000 \mathrm{rpm}$ for $5 \mathrm{~min}$ and the resulting Pal- $\mathrm{NH}_{2}$ nanorods were washed with ethanol to remove unreacted material, and dried in vacuum at $60^{\circ} \mathrm{C}$ for $2 \mathrm{~h}$. The product was stored in sealed bottle for later use.

\subsection{Preparation of Pal- $\mathrm{NH}_{2} @ \mathrm{AuPd}$, Pal- $\mathrm{NH}_{2} @ \mathrm{Au}$, Pal- $\mathrm{NH}_{2} @ P d$}

The concentrations of both $\mathrm{HAuCl}_{4}$ and $\mathrm{K}_{2} \mathrm{PdCl}_{4}$ were fixed at $10 \mathrm{mM}$ during the whole preparation. The typical procedure for synthesis of $\mathrm{Pal}-\mathrm{NH}_{2} @ \mathrm{Au}_{48} \mathrm{Pd}_{52}$ is as follows. A quantity of $50 \mathrm{mg}$ of Pal- $\mathrm{NH}_{2}$ was dispersed in $5.0 \mathrm{~mL}$ aqueous solution via ultra-sonication and then $0.48 \mathrm{~mL}$ $\mathrm{HAuCl}_{4}$ and $0.52 \mathrm{~mL} \mathrm{~K}_{2} \mathrm{PdCl}_{4}$ were gradually added to the above solution. The resulting reaction mixture was kept in a glass bottle under stirring for $3 \mathrm{~h}(3000 \mathrm{rpm})$. Then freshly prepared $1.0 \mathrm{~mL}$ $\mathrm{NaBH}_{4}$ aqueous solution $(28 \mathrm{mg}, 0.7 \mathrm{mmol}$ ) was added and the reaction mixture was maintained at room temperature for another $0.5 \mathrm{~h}$. Then, the resulting solution was centrifuged ( $5000 \mathrm{rpm}, 5 \mathrm{~min}$ ) and washed with pure water three times ( 5 min each time) to remove the remaining reagents and then dried in vacuum at $60{ }^{\circ} \mathrm{C}$ for $2 \mathrm{~h}$. For comparison, Pal-NH $\mathrm{NH}_{2} @ \mathrm{Au}_{33} \mathrm{Pd}_{67}\left(0.33 \mathrm{~mL} \mathrm{HAuCl}{ }_{4}\right.$ and $0.67 \mathrm{~mL}$ $\left.\mathrm{K}_{2} \mathrm{PdCl}_{4}\right)$ and $\mathrm{Pal}-\mathrm{NH}_{2} @ \mathrm{Au}_{81} \mathrm{Pd}_{19}\left(0.81 \mathrm{~mL} \mathrm{HAuCl}{ }_{4}\right.$ and $\left.0.19 \mathrm{~mL} \mathrm{~K}_{2} \mathrm{PdCl}_{4}\right)$ were also prepared using the same method by adjusting the molar ratios of $\mathrm{Au} / \mathrm{Pd}$ precursors. Only $1 \mathrm{~mL} \mathrm{HAuCl} \mathrm{H}_{4}$ and $1 \mathrm{~mL}$ $\mathrm{K}_{2} \mathrm{PdCl}_{4}$ were used for the preparation of Pal-NH $\mathrm{NH}_{2} @ \mathrm{Au}$ and Pal-NH $\mathrm{N}_{2} @ \mathrm{Pd}$, respectively.

\subsection{Catalytic Reduction of Nitrobenzene}

In order to examine the catalytic activity of the Pal- $\mathrm{NH}_{2} @ \mathrm{Au}_{48} \mathrm{Pd}_{52}$ nano-catalysts, we chose the reduction of 4-NP with the help of $\mathrm{NaBH}_{4}$ at room temperature as a model reaction. In a typical procedure, $0.25 \mathrm{~mL}$ freshly prepared $\mathrm{NaBH}_{4}$ solution $(1.2 \mathrm{M})$ was mixed with $0.25 \mathrm{~mL}$ of 4-NP $\left(3.4 \times 10^{-3} \mathrm{M}\right)$ and $8 \mathrm{~mL}$ of deionized water in a glass bottle, followed by addition of $0.02 \mathrm{~mL}$ Pal- $\mathrm{NH}_{2} @ \mathrm{Au}_{48} \mathrm{Pd}_{52}$ solution $(1 \mathrm{mg} / \mathrm{mL}$ ) to the mixture. The color of the solution gradually vanished as the reaction proceeded. The progress of the reaction solution was immediately recorded using UV-Vis spectra at $1 \mathrm{~min}$ intervals. The catalytic reductions of other nitrobenzenes were conducted under the same conditions as for 4-NP. To evaluate the reusability of catalyst, the catalysts were collected by centrifugation ( $8000 \mathrm{rpm}, 3 \mathrm{~min}$ ), washed with pure water, dried at $60^{\circ} \mathrm{C}$ and reused for reduction under the same conditions in the next cycles.

\subsection{Preparation of Artificial Wastewater}

The artificial wastewater was prepared as in the reported procedure [32]. Artificial wastewater was prepared by mixing starch ( $25 \mathrm{mg} / \mathrm{L})$, sucrose $(15 \mathrm{mg} / \mathrm{L}), \mathrm{CR}(2.5 \mathrm{mg} / \mathrm{L}), \mathrm{RR}(2.5 \mathrm{mg} / \mathrm{L})$, acetic acid (5 mg/L), sulphuric acid $(7.5 \mathrm{mg} / \mathrm{L})$, sodium hydroxide $(12.5 \mathrm{mg} / \mathrm{L})$, sodium carbonate $(12.5 \mathrm{mg} / \mathrm{L})$, sodium chloride $(75 \mathrm{mg} / \mathrm{L})$, and sodium dodecyl sulphate $(2.75 \mathrm{mg} / \mathrm{L})$ in a $1000 \mathrm{~mL}$ volumetric flask. The $\mathrm{pH}$ of the resulting solution was 9.5 .

\subsection{Treatment of Artificial Wastewater with Pal-NH$H_{2} @ A u_{48} P d_{52}$}

A quantity of $3 \mathrm{~mL}$ of artificial wastewater was decolorized by adding $40 \mu \mathrm{g} P \mathrm{Pal}-\mathrm{NH}_{2} @ \mathrm{Au}_{48} \mathrm{Pd}_{52}$ and $100 \mu \mathrm{L}$ of $50 \mathrm{mM} \mathrm{NaBH}_{4}$. The reaction progress was monitored by ultraviolet-visible (UV-Vis) spectrometry at a certain time interval to obtain successive information. 


\subsection{Characterization}

Transmission electron microscopy (TEM), high resolution transmission electron microscopy (HRTEM), and the energy dispersive spectra (EDS) were determined using a Tecnai-G2-F30 (FEI, Eindhoven, The Netherlands) at acceleration voltages of $200 \mathrm{kV}$. Powder X-ray diffraction patterns (PXRD) were recorded on a Rigaku-Dmax 2400 diffractometer using $\mathrm{Cu} \mathrm{K} \alpha$ radiation (Rigaku Dmax-2400, Rigaku Corporation, Tokyo, Japan). UV-vis absorption spectra were investigated using a Perkin Elmer Lambda 950 spectrophotometer (Lambda950, Perkin-Elmer, Waltham, MA, USA). The content of Au and Pd was determined by inductively coupled plasma-atomic emission spectroscopy (ICP-AES, ICPE-9800, Shimadzu Corporation, Kyoto, Japan).

\section{Results and Discussion}

\subsection{Structural and Morphology Characterization}

X-ray diffraction (XRD) patterns were used to characterize the alloy Pal- $\mathrm{NH}_{2} @ \mathrm{Au}_{48} \mathrm{Pd}_{52}$ structure. Figure 1 shows the XRD patterns of Pal, Pal- $\mathrm{NH}_{2} @ \mathrm{Au}, \mathrm{Pal}-\mathrm{NH}_{2} @ \mathrm{Pd}$, and Pal- $\mathrm{NH}_{2} @ \mathrm{Au}_{48} \mathrm{Pd}_{52}$. The weak and broad diffraction peaks at $20=8.3^{\circ}, 19.7^{\circ}$, and $26.6^{\circ}$ were assigned to the diffraction of (110), (040) and (231) planes of palygorskite (JCPDS No. 31-0783) [33] for each sample. The results clearly indicated that the two-plane characteristic peaks for $\mathrm{Pal}$ and $\mathrm{Pal}-\mathrm{NH}_{2}$ did not change, which demonstrated that the original inner structure of palygorskite was not damaged during the whole preparation of Pal- $\mathrm{NH}_{2} @ \mathrm{Au}_{48} \mathrm{Pd}_{52}$. The peaks at $2 \theta$ values of $40.4^{\circ}, 46.5^{\circ}, 68.4^{\circ}$ and $82.1^{\circ}$ corresponded to the (111), (200), (220) and (311) planes of face-centered cubic structures of the Pd (JCPDS No. 65-2867) [34]. Pal- $\mathrm{NH}_{2} @ \mathrm{Au}$ exhibited four characteristic peaks at $2 \theta$ of $38.2^{\circ}, 44.6^{\circ}, 64.6^{\circ}$ and $77.5^{\circ}$, consistent with the lattice structure of Au (JCPDS No. 65-8601) [35]. Although the Pal- $\mathrm{NH}_{2}$-supported $\mathrm{Au}_{48} \mathrm{Pd}_{52}$ alloy nano-catalysts also exhibited four peaks at $2 \theta$ of $39.3^{\circ}, 45.5^{\circ}, 65.8^{\circ}$ and $79.5^{\circ}$, these peaks lay between monometallic $\mathrm{Au}$ and Pd peaks. Thus, we could demonstrate that $\mathrm{Pd}$ and $\mathrm{Au}$ atoms had penetrated into each other's mutual lattice and formed a AuPd bimetallic alloy structure [36,37].

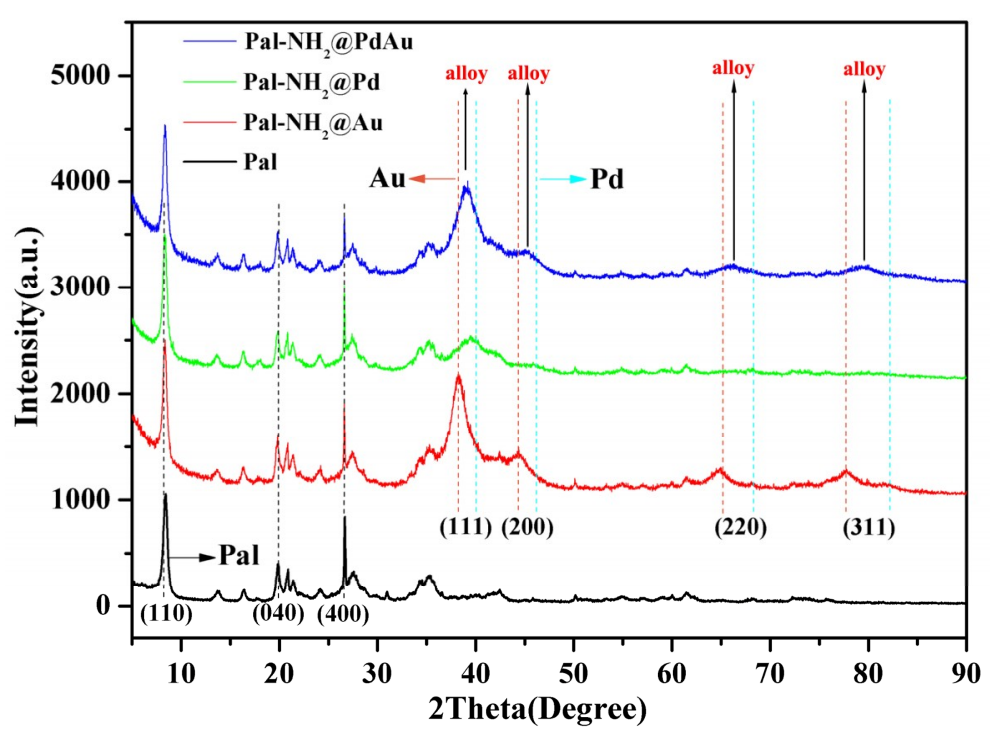

Figure 1. X-ray diffraction (XRD) patterns of Pal, Pal-NH $\mathrm{NH}_{2} @ \mathrm{Au}, \mathrm{Pal}-\mathrm{NH}_{2} @ \mathrm{Pd}$ and Pal- $\mathrm{NH}_{2} @ \mathrm{AuPd}$.

In order to further investigate the surface states of AuPd bimetallic alloy NPs on the surface of Atta, the Pal- $\mathrm{NH}_{2} @ \mathrm{Au}_{48} \mathrm{Pd}_{52}$ sample was examined by high-resolution X-ray photoelectron spectroscopy (XPS) analysis of Au $4 \mathrm{f}$ and Pd 3d. As shown in Figure $2 \mathrm{a}$, the $A u 4 f_{7 / 2}$ and $A u 4 f_{5 / 2}$ peaks of Pal- $\mathrm{NH}_{2} @ \mathrm{Au}_{48} \mathrm{Pd}_{52}$ alloy located at 83.8 and $87.6 \mathrm{eV}$ can be attributed to metallic $\mathrm{Au}^{0}$, which exhibits a slight downshift compared to that of monometallic Au nanoparticles [38]. Furthermore, the Pd $3 d$ spectra (Figure $2 b$ ) of the AuPd bimetallic alloy sample could be fitted into two peaks (336.9 and 
$342.0 \mathrm{eV}$ ), which can be attributed to $3 \mathrm{~d}_{5 / 2}$ and $3 \mathrm{~d}_{3 / 2}$ of $\mathrm{Pd}^{0}$, respectively. In addition, the XPS signals of $\mathrm{Pd} 3 \mathrm{~d}$ showed a greater binding energy than that of monometallic Pd-doped nanoparticles $[38,39]$. The above changes in binding energy were attributed to the formation of AuPd bimetallic alloy [25,40,41], which was in good agreement with XRD characterization.
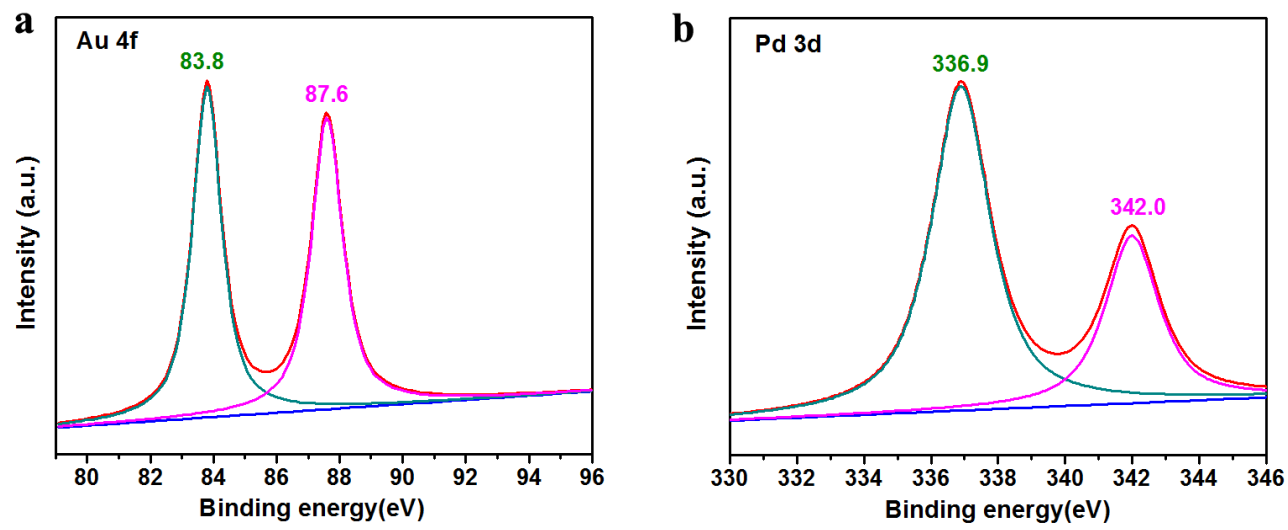

Figure 2. X-ray photoelectron spectroscopy (XPS) spectra of the $\mathrm{Pal}_{-\mathrm{NH}_{2}} @ \mathrm{Au}_{48} \mathrm{Pd}_{52}$ sample: (a) $\mathrm{Au} 4 \mathrm{f}$ and (b) Pd 3d.

The morphologies of Pal- $\mathrm{NH}_{2}$ and Pal- $\mathrm{NH}_{2} @ \mathrm{Au}_{48} \mathrm{Pd}_{52}$ were characterized by transmission electron microscopy (TEM), as shown in Figure $3 \mathrm{a}-\mathrm{c}$, indicating that the palygorskite continued to maintain the rod-like morphology after surface modification. This special rod-like morphology also made it possible for it to act as a carrier, allowing AuPd bimetallic nanoparticles to be modified onto the surface of $\mathrm{Pal}$ by the simple nucleation and co-precipitation process. From Figure $3 \mathrm{~b}$ we can see that many small nanoparticles appeared on Pal surface, demonstrating the successful loading of the AuPd alloy nano-catalyst without obvious aggregation. The white spots and gray shell on the high angle annular dark-field scanning transmission electron microscopy (HAADF-STEM) image in the top right corner of Figure $3 \mathrm{~b}$ also illustrate that the AuPd alloy nano-catalysts were modified on the surface of Pal; the average size of AuPd nano-catalysts was about $3.1 \mathrm{~nm}$. Furthermore, the typical High Resolution Transmission Electron Microscope (HRTEM) image (Figure 3c) showed the arrangement of the AuPd NPs, where AuPd NPs were seen as having various orientations and lattice spacing. By carefully measuring the lattice parameters using a digital micrograph and comparing them with the data in Joint Committee on Powder Diffraction Standards (JCPDS), five different kinds of lattice fringes were clearly observed. However, no diffraction peaks corresponding to Au or Pd NPs can be observed in Figure 3c. Therefore, it was deduced that the remaining intervals belong to AuPd alloys. Meanwhile, the energy-dispersive X-ray spectroscopy (EDX) spectrum of the Pal- $\mathrm{NH}_{2} @ \mathrm{AuPd}$ (Figure 3d) exhibited the presence of $\mathrm{Al}, \mathrm{Si}, \mathrm{Mg}, \mathrm{Au}$, and Pd elements, which also proved the successful deposition of $\mathrm{AuPd}$ on the surface of Pal- $\mathrm{NH}_{2}$. Inductively coupled plasma-atomic emission spectroscopy (ICP-AES) was used to determine the Au or Pd contents (as shown in Table 1) of the original $\mathrm{Pal}-\mathrm{NH}_{2}$, which were consistent with the designed ratio.

The distribution of each element on the surface of $\mathrm{Pal}-\mathrm{NH}_{2} @ \mathrm{Au}_{48} \mathrm{Pd}_{52}$ were further investigated by EDS-mapping and EDX. High angle annular dark-field scanning transmission electron microscopy (HAADF-STEM) measurements (Figure 4) were used to study the stereo distribution of Pd and $\mathrm{Au}$. Here, it is necessary to mention that it was difficult to obtain HAADF-STEM results for the ultrafine AuPd NPs and it is normal when the nanoparticles had small size, organic liagnds and heavy atoms. During the operation of the HAADF-STEM we can't focus the light on all of the nanoparticles, when the focus and exposure time was too long, carbonization would happen on some of the NPs, which may reduce the clarity of the picture. The dark-field images indicated an abundant deposition of AuPd nano-catalysts on the Pal- $\mathrm{NH}_{2}$ support. Clearly from Figure 4, Si, $\mathrm{Al}, \mathrm{N}, \mathrm{Au}$, and $\mathrm{Pd}$ atoms were distributed on $\mathrm{Pal}-\mathrm{NH}_{2}$, while $\mathrm{Pd}$ and $\mathrm{Au}$ atoms were distributed uniformly over 
the entire Pal- $\mathrm{NH}_{2} @ \mathrm{Au}_{48} \mathrm{Pd}_{52}$ nano-catalysts, which provided strong evidence regarding the formation of alloy-decorated nano-catalysts [37].
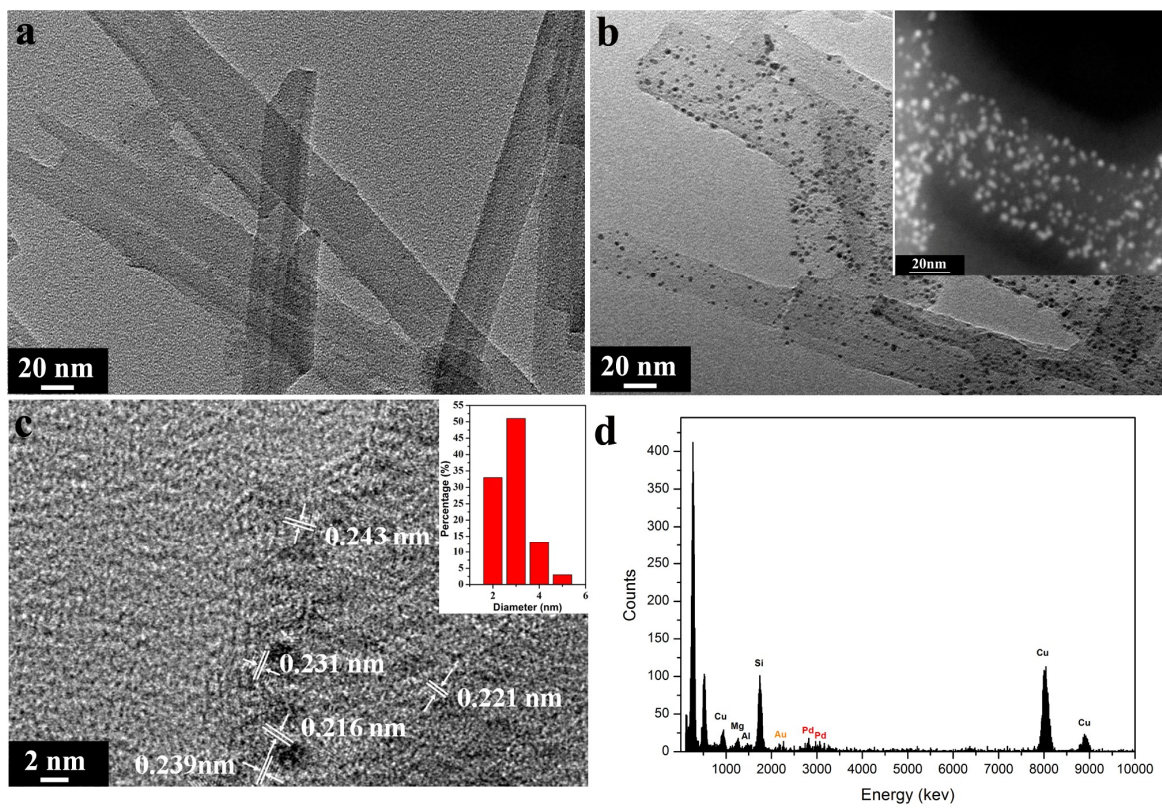

Figure 3. The transmission electron microscopy (TEM) images of the $\mathrm{Pal}_{-\mathrm{NH}_{2}}$ (a) and Pal- $\mathrm{NH}_{2} @ \mathrm{Au}_{48} \mathrm{Pd}_{52}(\mathbf{b}, \mathbf{c})$, and the energy-dispersive X-ray spectroscopy (EDX) spectrum of Pal- $\mathrm{NH}_{2} @ \mathrm{Au}_{48} \mathrm{Pd}_{52}$ nano-catalysts (d); The top right corner of $\mathbf{b}$ is the high angle annular dark-field

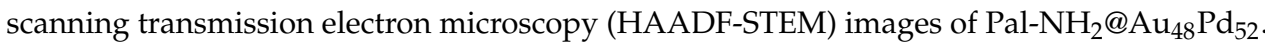

Table 1. Summary of the molar ratios between $\mathrm{Au}$ and $\mathrm{Pd}$, the weight percentage of $\mathrm{Au}$ and $\mathrm{Pd}$ (based on ICP-MS results), the rate constants of the reaction (k), and the turnover frequency (TOF) values.

\begin{tabular}{ccccc}
\hline Catalysts & $\mathbf{A u}(\mathbf{w t} \mathbf{\%})$ & $\mathbf{P d}(\mathbf{w t} \mathbf{\%})$ & $\mathbf{K}\left(\mathbf{M i n}^{-\mathbf{1}}\right)$ & $\mathbf{T O F}\left(\mathbf{M i n}^{-\mathbf{1}}\right)$ \\
\hline $\mathrm{Au}$ & 3.94 & 0 & 0.021 & 4.25 \\
$\mathrm{Pd}$ & 0 & 2.12 & 0.071 & 7.08 \\
$\mathrm{Au}_{33} \mathrm{Pd}_{67}$ & 1.32 & 1.41 & 0.132 & 12.39 \\
$\mathrm{Au}_{48} \mathrm{Pd}_{52}$ & 1.81 & 1.10 & 0.194 & 16.51 \\
$\mathrm{Au}_{81} \mathrm{Pd}_{19}$ & 3.19 & 0.40 & 0.102 & 10.11 \\
\hline
\end{tabular}
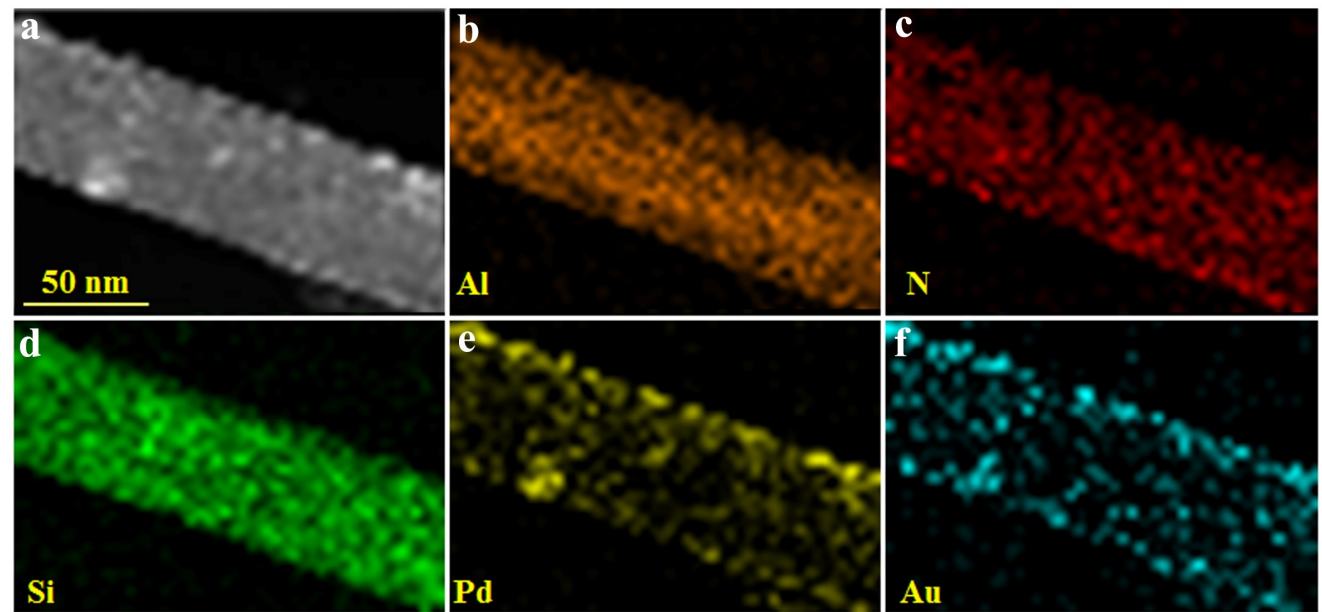

Figure 4. HAADF-STEM images of Pal- $\mathrm{NH}_{2} @ \mathrm{Au}_{48} \mathrm{Pd}_{52}$ (a); EDX mapping: of $\mathrm{Al}$ element (b); $\mathrm{N}$ element (c); Si element (d); Pd element (e) and Au element (f). 


\subsection{Catalytic Activity}

Inspired by the attractive properties of the AuPd alloy nanoparticles on Pal, such as their monodisperse, ultrafine and pristine nature, we investigated the catalytic ability of the as-prepared Pal- $\mathrm{NH}_{2} @ \mathrm{AuPd}$. The reduction of 4-NP to 4-aminophenol (4-AP) was carried out as a test reaction using $\mathrm{NaBH}_{4}$ as the reducing agent and Pal- $\mathrm{NH}_{2} @ \mathrm{AuPd}$ as the catalyst. UV-Vis absorption spectra were used to illustrate the reduction process of 4-NP. Generally, the solution of 4-NP had a distinct absorption peak at $317 \mathrm{~nm}$. However, after the addition of an aqueous solution of $\mathrm{NaBH}_{4}$, this peak was remarkably red-shifted to $400 \mathrm{~nm}$ owing to the formation of 4-nitrophenolate [42], as shown in Figure $5 \mathrm{a}$. The process was also accompanied by a color change from light yellow to bright yellow. With the addition of $\mathrm{Pal}-\mathrm{NH}_{2} @ \mathrm{Au}_{48} \mathrm{Pd}_{52}$ catalyst, the absorption peak at $400 \mathrm{~nm}$ gradually disappeared and a new peak appeared at $300 \mathrm{~nm}$, which corresponded to 4-AP [43], as shown in Figure 5b. Meanwhile, the bright yellow solution became colorless over time, which indicated that the reduction of 4-NP was complete. Furthermore, as shown in Figure $5 c$,d, it was noticed that the absorption intensities at $400 \mathrm{~nm}$ of the Pal- $\mathrm{NH}_{2} @ \mathrm{Au}_{48} \mathrm{Pd}_{52}$ nano-catalysts decreased much faster in comparison to $\mathrm{Pal}-\mathrm{NH}_{2} @ \mathrm{Au}$ and Pal- $\mathrm{NH}_{2} @ \mathrm{Pd}$, which indicated that Pal- $\mathrm{NH}_{2} @ \mathrm{Au}_{48} \mathrm{Pd}_{52}$ nano-catalysts had better catalytic activity. As to the possible catalytic mechanism of this reduction, the Pal- $\mathrm{NH}_{2} @ \mathrm{Au}_{48} \mathrm{Pd}_{52}$ may serve as an electron relay system and play a significant role in the electron transfer (ET) process. The 4-NP molecule and $\mathrm{BH}_{4}{ }^{-}$ion were first adsorbed to the surface of the $\mathrm{Pal}_{-} \mathrm{NH}_{2} @ \mathrm{AuPd}$ and the large specific surface area of the Pal- $\mathrm{NH}_{2} @$ AuPd catalysts resulted in the concentration increase near the surface of the Pal- $\mathrm{NH}_{2} @ \mathrm{AuPd}$. Then, ET from $\mathrm{BH}_{4}{ }^{-}$to the 4-NP via the Pal- $\mathrm{NH}_{2} @ \mathrm{AuPd}$ became easier and directly accelerated the reduction reaction rate [44].
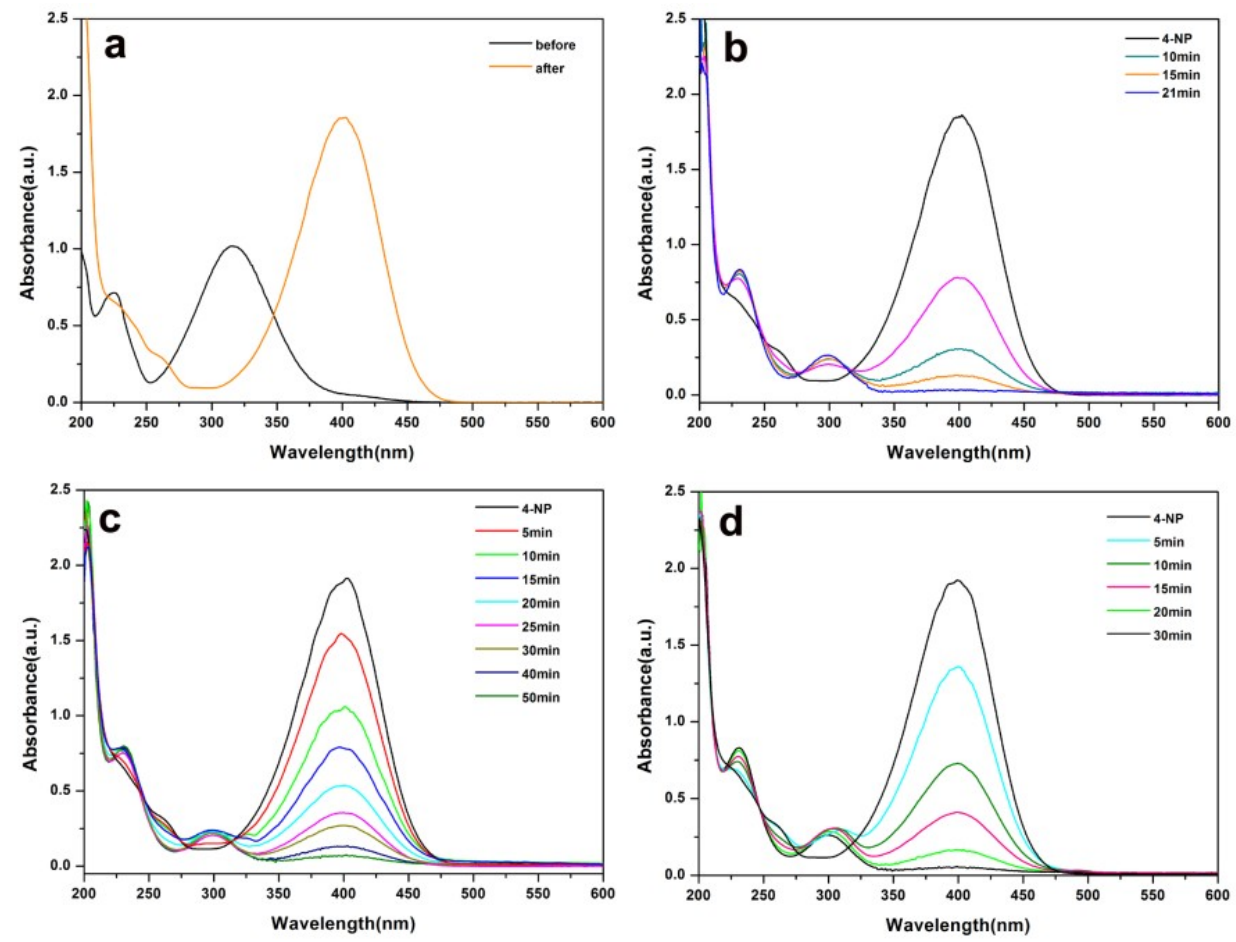

Figure 5. (a) UV-Vis absorption spectra of 4-NP before and after the addition of $\mathrm{NaBH}_{4}$ solution without catalyst: variation in UV-Vis spectra intervals for the 4-nitrophenol (4-NP) reduction in the presence of (b) Pal- $\mathrm{NH}_{2} @ \mathrm{Au}_{48} \mathrm{Pd}_{52}$; (c) Pal- $\mathrm{NH}_{2} @ \mathrm{Au}$; and (d) Pal- $\mathrm{NH}_{2} @ \mathrm{Pd}$.

Since the amount of $\mathrm{NaBH}_{4}$ used was in excess compared to 4-NP, the concentration of $\mathrm{BH}_{4}{ }^{-}$ remained almost constant throughout the reaction progress. In this way, a pseudo first-order kinetics equation with respect to the 4-NP was applied to calculate the apparent rate constant $\left(K_{\text {app }}\right)$, as follows: $k_{\mathrm{app}} t=\ln \left(C_{t} / C_{0}\right) . C_{t}$ and $C_{0}$ represented the concentrations of 4-NP at intervals and the initial stage, 
respectively. Figure 6a exhibits the linear plots of $\ln \left(C_{t} / C_{0}\right)$ versus reaction time for the reaction catalyzed by Pal- $\mathrm{NH}_{2} @ \mathrm{Au}_{48} \mathrm{Pd}_{52}$ and supported monometallic samples. The apparent rate constants were 0.194, 0.021, and $0.071 \mathrm{~min}^{-1}$ for the Pal-NH $\mathrm{NH}_{2} @ \mathrm{Au}_{48} \mathrm{Pd}_{52}, \mathrm{Pal}-\mathrm{NH}_{2} @ \mathrm{Au}$, and Pal- $\mathrm{NH}_{2} @ \mathrm{Pd}$, respectively, demonstrating that the catalytic activity of the AuPd alloy nano-catalysts were roughly 9 and 2.7 times higher than that of their monometallic counterparts. In order to further investigate the effect of the catalytic performance of the alloy NPs, the Pal- $\mathrm{NH}_{2} @ \mathrm{AuPd}$ with different $\mathrm{Au} / \mathrm{Pd}$ ratios were prepared by varying the feeding amounts of $\mathrm{K}_{2} \mathrm{PdCl}_{4}$. The plot of $\ln \left(C_{t} / C_{0}\right)$ versus reaction time was also observed for the Pal- $\mathrm{NH}_{2} @ \mathrm{AuPd}$ with different $\mathrm{Au} / \mathrm{Pd}$ ratios catalyzing under the same condition. As recognized from the change in the rate constants and turnover frequency (TOF) values with the $\mathrm{Au}$ and Pd mole fraction (Figure 6a and Table 1), we could conclude that the catalytic property was directly dependent upon the composition of the AuPd alloy NPs, and that the Pal- $\mathrm{NH}_{2} @ \mathrm{Au}_{48} \mathrm{Pd}_{52}$ exhibited the best catalytic activity. This super-catalytic activity of $\mathrm{Pal}-\mathrm{NH}_{2} @ \mathrm{Au}_{48} \mathrm{Pd}_{52}$ bimetallic nano-catalysts may be due to the synergistic effect between $\mathrm{Au}$ and Pd NPs, as evidenced by extra charge interaction between Pd and Au NPs in Pal-NH $\mathrm{N}_{2} \mathrm{Au}_{48} \mathrm{Pd}_{52}$. Furthermore, the TEM images of the Pal- $\mathrm{NH}_{2} @ \mathrm{Au}, \mathrm{Pal}-\mathrm{NH}_{2} @ \mathrm{Pd}, \mathrm{Pal}-\mathrm{NH}_{2} @ \mathrm{Au}_{33} \mathrm{Pd}_{67}$ and Pal-NH $\mathrm{NH}_{2} @ \mathrm{Au}_{81} \mathrm{Pd}_{19}$ are also shown in Figure S1. We can see that the sizes of $\mathrm{Au}$ or Pd NPs on Pal-NH${ }_{2}$ surface were smaller than that of $\mathrm{Au}_{33} \mathrm{Pd}_{67}$ or $\mathrm{Au}_{81} \mathrm{Pd}_{19}$ alloy. In spite of the smaller monometallic catalysts, the $\mathrm{Au}_{48} \mathrm{Pd}_{52}$ alloy catalysts still showed the best catalytic activities, which is due to the synergistic effect between Au and Pd NPs, as evidenced by extra charge interaction between Pd and $\mathrm{Au}$ NPs in $\mathrm{Pal}-\mathrm{NH}_{2} @ \mathrm{Au}_{48} \mathrm{Pd}_{52}$.
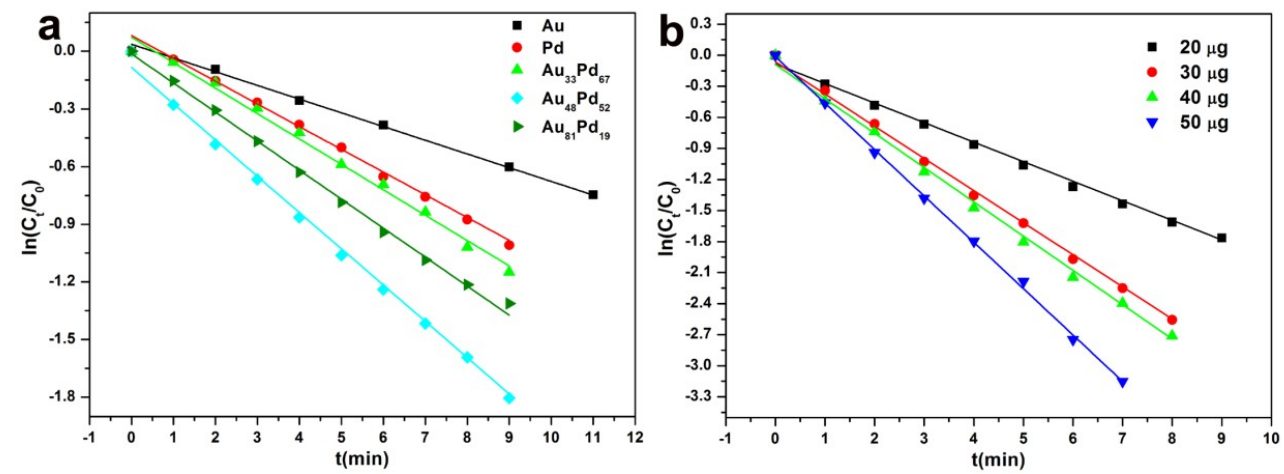

Figure 6. (a) Plot of $\ln \left(C_{t} / C_{0}\right)$ versus the reaction time for the reduction of 4-NP over different samples at $25{ }^{\circ} \mathrm{C}$; (b) Plot of $\ln \left(C_{t} / C_{0}\right)$ versus the reaction time for the reduction of 4-NP over different amounts of $\mathrm{Pal}-\mathrm{NH}_{2} @ \mathrm{Au}_{48} \mathrm{Pd}_{52}$.

In order to study the effect of catalyst loading on 4-NP degradation, the amount of Pal- $\mathrm{NH}_{2} @ \mathrm{Au}_{48} \mathrm{Pd}_{52}(20,30,40$ and $50 \mu \mathrm{g})$ was varied while maintaining fixed concentrations of 4-NP and $\mathrm{NaBH}_{4}$. The results obtained for quantitative analysis of the nano-catalysts for the 4-NP reduction as a function of time is shown in Figure $6 \mathrm{~b}$. It was observed that with an increasing the amount of the nano-catalysts, the reduction ability of 4-NP was enhanced rapidly and it was difficult to observe the progress of the reaction; this can be understood because the increase of catalyst dosage will

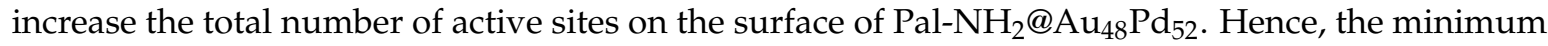
amount of $20 \mu \mathrm{g}$ catalyst was taken as an optimal catalyst concentration in this research.

In order to compare the catalytic activity of $\mathrm{Pal}-\mathrm{NH}_{2} @ \mathrm{Au}_{48} \mathrm{Pd}_{52}$ with other reported catalytic examples containing AuPd NPs in previous literature, we also compared reaction rate constant $(K)$ values according to the reported parameter $K=k_{\mathrm{app}} / N$ [45], where $N$ represents the molar ratio of Au-Pd alloy NPs $\left(n_{\mathrm{Au}}+n_{\mathrm{Pd}}\right)$ and 4-NP $\left(n_{4-\mathrm{NP}}\right)$. It is well known that the rate constant is influenced by many factors, such as metal nanoparticle loading, the usage of $\mathrm{NaBH}_{4}$, and catalysts dosage. In order to compare our results with other reports, we also listed the ratio of apparent rate constants $\left(k_{\text {app }}\right)$ over the molar ratio of AuPd catalysts and the concentration of 4-NP, named activity factor $K$, summarized in Table 2. It is worth noting that the activity factor $K$ value of $\mathrm{Pal}_{-} \mathrm{NH}_{2} @ \mathrm{Au}_{48} \mathrm{Pd}_{52}$ was 552.7 times 
higher than in $\mathrm{Au}_{1} \mathrm{Pd}_{4}$ core-shell nano-catalysts [46] and 5.6-116.2 times higher than in other reported 4-NP catalytic reactions [47-49]. In fact, in our catalytic system, each catalyst could achieve nearly $99 \%$ conversion of the substrates, so the ratio of Au-Pd alloy NPs $\left(n_{\mathrm{Au}}+n_{\mathrm{Pd}}\right)$ and $4-\mathrm{NP}\left(n_{4-\mathrm{NP}}\right)$ is $1 / \mathrm{TON}$ (where TON represents turnover number). Much of the literature adopted the apparent rate constant $k_{\text {app }}$ to express the speed of a reaction without considering the amount of catalyst used or the concentration of the substrates. If the amount of catalyst and the concentration of the substrates were not considered, the increase in the amount of the catalyst also caused an increase in the $k_{\text {app }}$ value. Similarly, the substrate concentration decreased and the reaction rate also decreased. Therefore, the calculation of the rate constant $\mathrm{K}$ must take into account the above two factors. In our catalytic reaction, the conversion rate of the substrate could reach $99 \%$, so we believed that the concentration of the substrate was the same as the concentration of the product. In order to thoroughly compare the catalytic efficiency of Pal- $\mathrm{NH}_{2} @ \mathrm{Au}_{48} \mathrm{Pd}_{52}$ nano-catalysts with other examples in the literature, we also calculated the TON and TOF values. As shown in Table 2, it was worth noting that the $K$, TON and TOF values of Pal-NH${ }_{2} @ \mathrm{Au}_{48} \mathrm{Pd}_{52}$ were higher than for many other nano-catalysts [44-47].

Table 2. Comparison of the activity of our catalysts with other reported catalysts in terms of the activity factor $K$ values and apparent rate constants.

\begin{tabular}{|c|c|c|c|c|c|c|}
\hline Catalysts & $\begin{array}{c}k_{\text {app }} \\
\left(\min ^{-1}\right)\end{array}$ & $\begin{array}{c}\left(n_{\mathrm{Au}}+\right. \\
\left.n_{\mathrm{Pd}}\right) / n_{4-\mathrm{NP}}\end{array}$ & $\begin{array}{c}\text { Turnover } \\
\text { Number (TON) }\end{array}$ & $\begin{array}{c}K \\
\left(\min ^{-1}\right)\end{array}$ & $\begin{array}{c}\text { TOF } \\
\left(\min ^{-1}\right)\end{array}$ & Reference \\
\hline Pal-NH$H_{2} @ \mathrm{Au}_{48} \mathrm{Pd}_{52}$ & 0.194 & 0.0047 & 212.77 & 45.116 & 11.82 & Here \\
\hline $\mathrm{Au}_{1} \mathrm{Pd}_{4}$ core/shell & 0.39 & 15.00 & 0.037 & 0.078 & 3 & [43] \\
\hline Pd@Au core-shell nanotetrapods & 0.139 & 0.380 & 2.63 & 0.366 & 0.035 & [44] \\
\hline Melamine cyanurate-Pd/Au & 0.280 & 0.0364 & 27.41 & 7.692 & 0.036 & [45] \\
\hline Au-on-Pd heteronanostructure & 0.867 & 0.16 & 33.33 & 5.419 & 9.52 & [46] \\
\hline
\end{tabular}

Furthermore, we investigated the catalytic activity of the Pal- $\mathrm{NH}_{2} @ \mathrm{Au}_{48} \mathrm{Pd}_{52}$ catalyst for the reduction of other four other kinds of nitroaniline nitrobenzene analogs, namely, p-Nitroaniline, m-Nitroaniline, o-Nitroanilineand, and 2,4-Nitroaniline (Table 3). The conversion was determined by the gas chromatography/mass spectroscopy (GC/MS) analysis of the residual nitrobenzene in the mixture after reaction. All the catalytic reaction progresses of other nitrobenzenes were conducted under the same conditions of 4-NP. As shown in Table 2, our catalyst displayed excellent catalytic behavior with excellent yields toward a series of nitrobenzene compounds regardless of different substituent groups. From Figure $7 \mathrm{a}-\mathrm{d}$ we can see the typical change of UV-Vis spectra of each compound during the reaction clearly demonstrated that the reduction of these nitrobenzenes did occur in the presence of a small amount of Pal- $\mathrm{NH}_{2} @ \mathrm{Au}_{48} \mathrm{Pd}_{52}$. The highest characteristic absorption peak of each substituent gradually weakened within 5-19 min, which also proved the excellent percentage conversion of the prepared Pal- $\mathrm{NH}_{2} @ \mathrm{Au}_{48} \mathrm{Pd}_{52}$ nano-catalysts.

Table 3. Reduction of various nitrobenzenes using $\mathrm{Pal}_{-\mathrm{NH}_{2}} @ \mathrm{Au}_{48} \mathrm{Pd}_{52}$ (Reaction condition: $0.25 \mathrm{~mL}$ of $3.4 \times 10^{-3} \mathrm{M}$ substrates and $0.25 \mathrm{~mL}$ of $1.2 \mathrm{M}$ fresh $\mathrm{NaBH}_{4}$ at the room temperature).

\begin{tabular}{lcccc}
\hline \multicolumn{1}{c}{ Compound } & Time/min & Conversion/\% & Amount of Catalyst/ug & TOF (min \\
\hline p-Nitroaniline & 20 & 99 & 20 & 9.88 \\
m-Nitroaniline & 10 & 99 & 20 & 19.77 \\
o-Nitroaniline & 5 & 99 & 20 & 39.54 \\
2,4-Nitroaniline & 19 & 99 & 20 & 10.40 \\
m-Nitrotoluene & 74 & 79 & 20 & 2.11 \\
o-Nitrotoluene & 86 & 85 & 20 & 1.95 \\
2,4-Dinitrotoluene & 97 & 89 & 20 & 1.81 \\
\hline
\end{tabular}



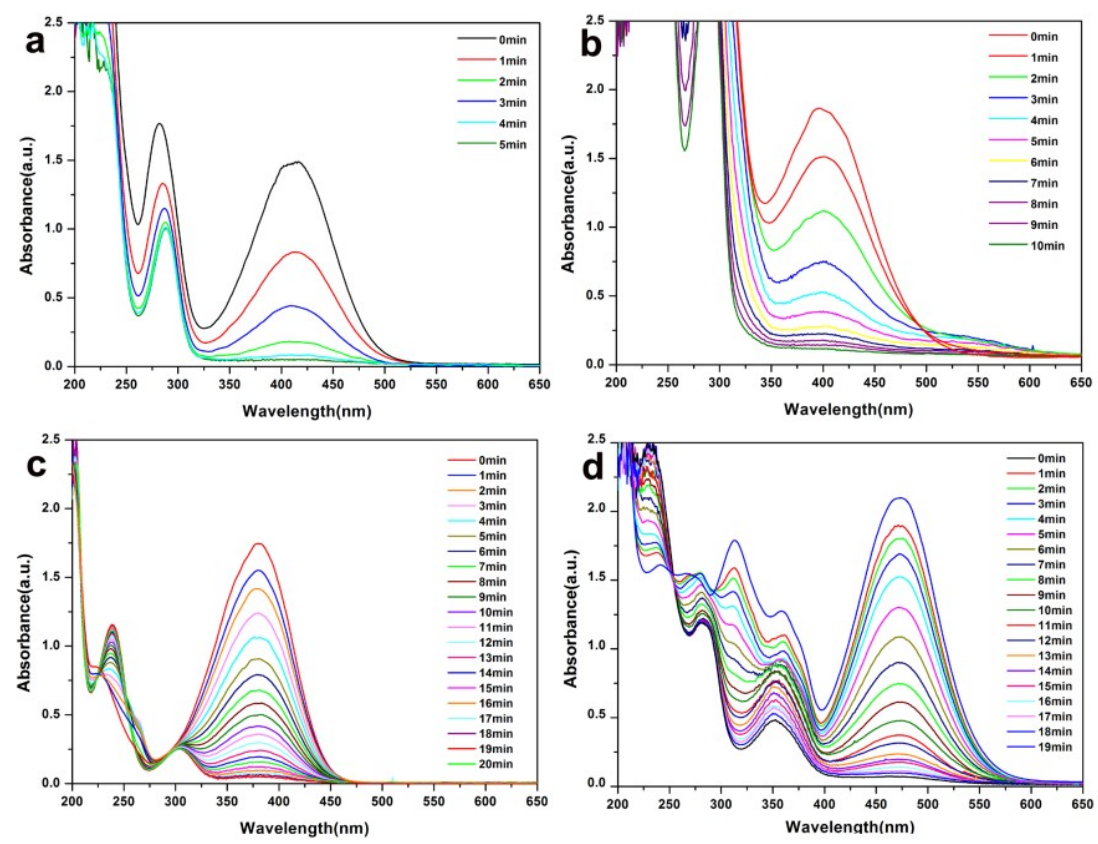

Figure 7. UV-Vis absorption spectra for the reduction of (a) o-Nitroaniline; (b) m-Nitroaniline; (c) p-Nitroaniline; (d) 2,4-Nitroaniline using Pal-NH $\mathrm{N}_{2} @ \mathrm{Au}_{48} \mathrm{Pd}_{52}$ nano-catalysts.

We also extended the application to investigate the catalytic activity of the $\mathrm{Pal}-\mathrm{NH}_{2} @ \mathrm{Au}_{48} \mathrm{Pd}_{52}$ nano-catalysts for the treatment of artificial wastewater [32]. From Figure 8a we can see that the typical absorption peaks of the organic dyes Congo red (CR) and reactive red (RR) in artificial wastewater appeared on the ultraviolet spectrum, demonstrating the main absorption peaks were 495 and $305 \mathrm{~nm}$. The two peaks of CR and RR showed a decreasing trend during the 110 min catalytic time, which indicated that the Pal- $\mathrm{NH}_{2} @ \mathrm{Au}_{48} \mathrm{Pd}_{52}$ nano-catalysts prepared also exhibited strong wastewater treatment ability under alkaline and high salinity conditions (Figure $8 \mathrm{~b}$ ). The conversion of the two organic dyes was more than $95 \%$ and the color of the artificial wastewater changed from red to colorless. This experiment provided evidence of a convenient and accessible means of degrading dyes in industrial wastewater, and we will further study dye degradation efficiency and the mechanism of the catalytic system in complex industrial wastewater in subsequent research.
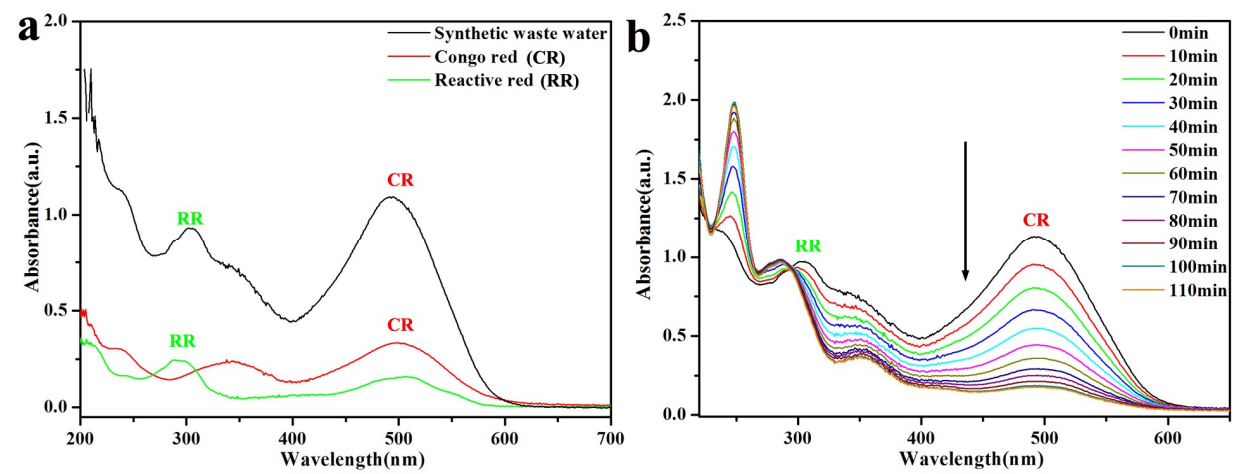

Figure 8. (a) The same concentration of artificial wastewater, using Congo red and reactive red; (b) artificial wastewater after the reduction by $\mathrm{NaBH}_{4}$ in the presence of $\mathrm{Pal}_{-} \mathrm{NH}_{2} @ \mathrm{Au}_{48} \mathrm{Pd}_{52}$.

The reusability of the nanocomposite catalysts is an important feature to be strongly considered in practical heterogeneous catalytic applications. In this study, the reusability of the Pal- $\mathrm{NH}_{2} @ \mathrm{Au}_{48} \mathrm{Pd}_{52}$ was evaluated as an example, by conducting the reduction of 4-NP for six cycles. As illustrated in Figure 9a, the Pal- $\mathrm{NH}_{2} @ \mathrm{Au}_{48} \mathrm{Pd}_{52}$ catalyst displayed good catalytic activity after five cycles without any significant loss of activity and selectivity. In the fifth run, the conversion yield of 4-NP was as high 
as $96 \%$, indicating the excellent recyclability of the Pal- $\mathrm{NH}_{2} @ \mathrm{Au}_{48} \mathrm{Pd}_{52}$ catalyst. To further confirm the stability of the $\mathrm{Pal}-\mathrm{NH}_{2} @ \mathrm{Au}_{48} \mathrm{Pd}_{52}$ nano-catalysts, the sample was collected after five successive catalytic runs and the structure was examined by TEM measurement. From the TEM image in Figure 9b we can clearly see that there were no obvious changes, either in the morphology or the particle size distribution, as compared to the original nano-catalyst. This high recycling stability of the prepared Pal- $\mathrm{NH}_{2} @ \mathrm{Au}_{48} \mathrm{Pd}_{52}$ nano-catalyst indicated that it can be a material of choice for the reduction of 4-NP.
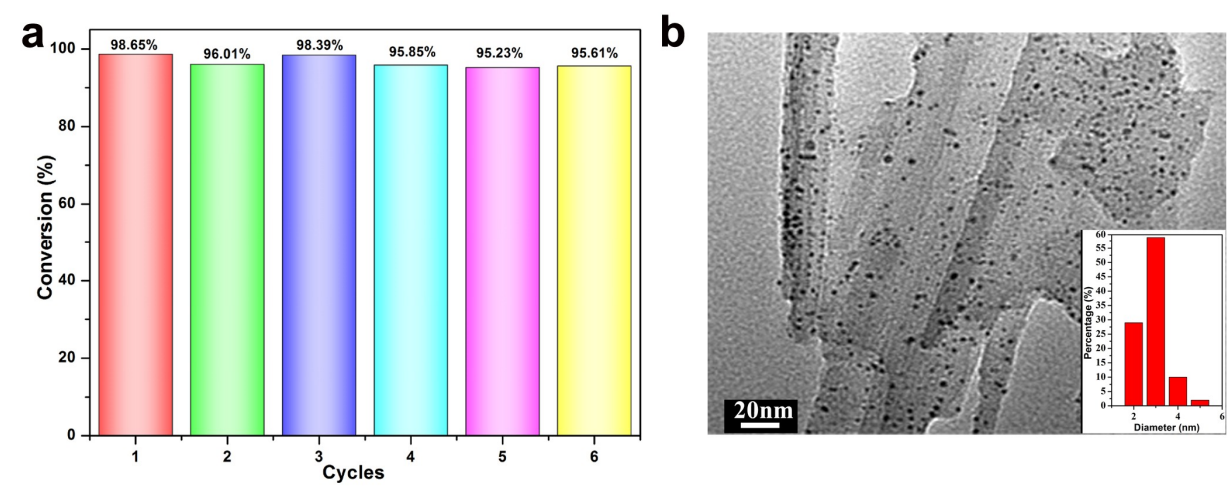

Figure 9. (a) The reusability test of Pal- $\mathrm{NH}_{2} @ \mathrm{Au}_{48} \mathrm{Pd}_{52}$ catalyst in five cycles; (b) the morphology and the particle size distribution (inset) of the $\mathrm{Pal}-\mathrm{NH}_{2} @ \mathrm{Au}_{48} \mathrm{Pd}_{52}$ catalyst after successive cycles.

\section{Conclusions}

In conclusion, we reported an effective and stable noble Pal- $\mathrm{NH}_{2} @ \mathrm{AuPd}$ alloy nano-catalyst for the reduction of 4-NP with $\mathrm{NaBH}_{4}$ under mild reaction conditions. The activity of bimetallic AuPd nanoparticles can be greatly enhanced after adjusting the suitable molar ratio of $\mathrm{Au}$ and $\mathrm{Pd}$ atoms. Compared to the original monometallic nanocomposite ( $\mathrm{Pal}-\mathrm{NH}_{2} @ \mathrm{Au}$ and $\mathrm{Pal}-\mathrm{NH}_{2} @ \mathrm{Pd}$ ), the alloy Pal- $\mathrm{NH}_{2} @ \mathrm{Au}_{48} \mathrm{Pd}_{52}$ indicated excellent catalytic activities toward the reduction of 4-nitrophenol. This method, used for the decoration of bimetallic nano-catlysts, was simple and versatile, and no stabilizer was necessary for the growth of the bimetallic nanoparticles, which is of considerable technological importance. Furthermore, Pal- $\mathrm{NH}_{2} @ \mathrm{Au}_{48} \mathrm{Pd}_{52}$ also indicated excellent activities in the reduction of other nitroarenes and dyes in artificial wastewater, regardless of the alkaline and high salinity conditions. Thus, as a fascinating rod-like structure, amine groups-modified palygorskite can be potentially used as a novel catalyst to support bimetallic AuPd hybrids or other metal catalysts.

Supplementary Materials: The following are available online at http://www.mdpi.com/2079-4991/8/12/

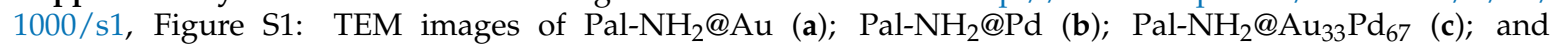
Pal- $\mathrm{NH}_{2} @ \mathrm{Au}_{81} \mathrm{Pd}_{19}(\mathbf{d})$.

Author Contributions: J.X. and L.J. conceived and designed the experiments; S.G. and W.Z. performed the experiments and analyzed the data; L.J. provided the concept of this research and managed all the experimental and writing process as the corresponding authors; all authors discussed the results and commented on the manuscript.

Funding: This research was funded by the National Natural Science Foundation of China (51773052, 41371501, 21404033 and 21401046), the Program for Science \& Technology Innovation Talents in Universities of Henan Province (19HASTIT040), the Science Research Funds for the Universities of Henan Province (NSFRF170305, NSFRF1607), the Fundamental Research Funds for the Universities of Henan Province, the Science and Technology Research Project of Henan province (No. 182102310702 and No. 162102210065), the Foundation for Distinguished Young Scientists of Henan Polytechnic University (J2018-2), the Foundation of Clinical Science and Technology of Wuxi (No. MS201609, No. Z201610 and No. Z201709), the Foundation of Science and Technology of Yixing (No. 2016-10), and the Foundation of Wuxi Young Medical Talents (No. QNRC032).

Conflicts of Interest: The authors declare no conflict of interest. 


\section{References}

1. Wang, A.J.; Cheng, H.Y.; Liang, B.; Ren, N.Q.; Cui, D.; Lin, N.; Kim, B.H.; Rabaey, K. Efficient reduction of nitrobenzene to aniline with a biocatalyzed cathode. Environ. Sci. Technol. 2011, 45, 10186-1019393. [CrossRef]

2. Wei, W.; Sun, R.; Jin, Z.; Cui, J.; Wei, Z. Hydroxyapatite-gelatin nanocomposite as a novel adsorbent for nitrobenzene removal from aqueous solution. Appl. Surf. Sci. 2014, 292, 1020-1029. [CrossRef]

3. Wu, Y.G.; Wen, M.; Wu, Q.S.; Fang, H. Ni/graphene nanostructure and its electron-enhanced catalytic action for hydrogenation reaction of nitrophenol. J. Phys. Chem. C 2014, 118, 6307-6313. [CrossRef]

4. Andreou, D.; Iordanidou, D.; Tamiolakis, I.; Armatas, G.S.; Lykakis, I.N. Reduction of nitroarenes into aryl amines and $\mathrm{N}$-aryl hydroxylamines via activation of $\mathrm{NaBH}_{4}$ and ammonia-borane complexes by $\mathrm{Ag} / \mathrm{TiO}{ }_{2}$ catalyst. Nanomaterials 2016, 6, 54. [CrossRef]

5. Noschese, A.; Buonerba, A.; Canton, P.; Milione, S.; Capacchione, C.; Grassi, A. Highly efficient and selective reduction of nitroarenes into anilines catalyzed by gold nanoparticles incarcerated in a nanoporous polymer matrix: Role of the polymeric support and insight into the reaction mechanism. J. Catal. 2016, 340, 30-40. [CrossRef]

6. Guo, Y.; Li, J.; Zhao, F.; Lan, G.; Li, L.; Liu, Y.; Si, Y.; Jiang, Y.; Yang, B.; Yang, R. Palladium-modified functionalized cyclodextrin as an efficient and recyclable catalyst for reduction of nitroarenes. RSC. Adv. 2016, 6, 7950-7954. [CrossRef]

7. Shukla, A.; Singha, R.K.; Sasaki, T.; Bal, R. Nanocrystalline Pt-CeO $\mathrm{C}_{2}$ as an efficient catalyst for a room temperature selective reduction of nitroarenes. Green Chem. 2015, 17, 785-790. [CrossRef]

8. Dell'Anna, M.M.; Gallo, V.; Mastrorilli, P.; Romanazzi, G. A recyclable nanoparticle-supported rhodium catalyst for hydrogenation reactions. Molecules 2010, 15, 3311-3318. [CrossRef]

9. Astruc, D. Palladium nanoparticles as efficient green homogeneous and heterogeneous carbon-carbon coupling precatalysts: A unifying view. Inorg. Chem. 2007, 46, 1884-1894. [CrossRef]

10. Polavarapu, L.; Mourdikoudis, S.; Pastoriza-Santos, I.; Pérez-Juste, J. Nanocrystal engineering of noble metals and metal chalcogenides: controlling the morphology, composition and crystallinity. Cryst. Eng. Comm. 2015, 17, 3727-3762. [CrossRef]

11. Filice, M.; Marciello, M.; Morales, M.P.; Palomo, J.M. Synthesis of heterogeneous enzyme-metal nanoparticle biohybrids in aqueous media and their applications in $\mathrm{C}-\mathrm{C}$ bond formation and tandem catalysis. Chem. Commun. 2013, 49, 6876-6878. [CrossRef]

12. Dutta, S.; Sarkar, S.; Ray, C.; Roy, A.; Sahoo, R.; Pal, T. Mesoporous gold and palladium nanoleaves from liquid-liquid interface: enhanced catalytic activity of the palladium analogue toward hydrazine-assisted room-temperature 4-nitrophenol reduction. ACS Appl. Mater. Interfaces 2014, 6, 9134-9143. [CrossRef]

13. Wang, Z.M.; Xu, C.L.; Gao, G.Q.; Li, X. Facile synthesis of well-dispersed Pd-graphene nanohybrids and their catalytic properties in 4-nitrophenol reduction. RSC Adv. 2014, 4, 13644-13651. [CrossRef]

14. Wang, C.Y.; Boucher, M.; Yang, M.; Saltsburg, H.; Flytzani-Stephanopoulos, M. ZnO-modified zirconia as gold catalyst support for the low-temperature methanol steam reforming reaction. Appl. Catal. B Environ. 2014, 154-155, 142-152. [CrossRef]

15. Bychkov, V.Y.; Tyulenin, Y.P.; Gorenberg, A.Y.; Sokolov, S.; Korchak, V. Evolution of Pd catalyst structure and activity during catalytic oxidation of methane and ethane. Appl. Catal. A Gen. 2014, 485, 1-9. [CrossRef]

16. Zheng, G.; Kaefer, K.; Mourdikoudis, S.; Polavarapu, L.; Vaz, B.; Cartmell, S.E.; Bouleghlimat, A.; Buurma, N.J.; Yate, L.; de Lera, Á.R.; et al. Palladium nanoparticle-loaded cellulose paper: A highly efficient, robust, and recyclable self-assembled composite catalytic system. J. Phys. Chem. Lett. 2015, 6, 230-238. [CrossRef]

17. Le, X.; Dong, Z.; Li, X.; Zhang, W.; Le, M.; Ma, J. Fibrous nano-silica supported palladium nanoparticles: An efficient catalyst for the reduction of 4-nitrophenol and hydrodechlorination of 4-chlorophenol under mild conditions. Catal. Commun. 2015, 59, 21-25. [CrossRef]

18. Wang, C.; Zhang, H.; Feng, C.; Gao, S.; Shang, N.; Wang, Z. Multifunctional Pd@MOF core-shell nanocomposite as highly active catalyst for p-nitrophenol reduction. Catal. Commun. 2015, 72, 29-32. [CrossRef]

19. Notar, F.I.; Fontaine-Vive, F.; Antoniotti, S. Synergy in the catalytic activity of bimetallic nanoparticles and new synthetic methods for the preparation of fine chemicals. ChemCatChem 2014, 6, 2784-2791. [CrossRef]

20. Mourdikoudis, S.; Chirea, M.; Zanaga, D.; Altantzis, T.; Mitrakas, M.; Bals, S.; Liz-Marzán, L.M.; Pérez-Juste, J.; Pastoriza-Santos, I. Governing the morphology of Pt-Au heteronanocrystals with improved electrocatalytic performance. Nanoscale 2015, 7, 8739-8747. [CrossRef] 
21. Hirasawa, S.; Watanabe, H.; Kizuka, T.; Nakagawa, Y.; Tomishige, K. Performance, structure and mechanism of Pd-Ag alloy catalyst for selective oxidation of glycerol to dihydroxyacetone. J. Catal. 2013, 300, 205-216. [CrossRef]

22. Zhou, Y.; Wang, Z.; Liu, C. Perspective on CO oxidation over Pd-based catalysts. Catal. Sci. Technol. 2015, 5, 69-81. [CrossRef]

23. Jia, L.; Zhou, T.; Xu, J.; Xu, Z.; Li, H.; Liu, B.; Sun, J.; Cao, J.; Shen, X.; Li, X. Synthesis and characterization of $\mathrm{PdRu}$ alloy-coated palygorskite-based nanocomposites as a magnetically recyclable multifunctional catalyst for reduction of nitroarenes and azo dyes. Mater. Lett. 2017, 197, 24-27. [CrossRef]

24. Hosseini, H.; Mahyari, M.; Bagheri, A.; Shaabani, A. Pd and PdCo alloy nanoparticles supported on polypropylenimine dendrimer-grafted graphene: A highly efficient anodic catalyst for direct formic acid fuel cells. J. Power Sources 2014, 247, 70-77. [CrossRef]

25. Karatas, Y.; Bulut, A.; Yurderi, M.; Ertas, I.E.; Alal, O.; Gulcan, M. PdAu-MnO $\mathrm{x}_{\mathrm{x}}$ nanoparticles supported on amine-functionalized $\mathrm{SiO}_{2}$ for the room temperature dehydrogenation of formic acid in the absence of additives. Appl. Catal. B Environ. 2016, 180, 586-595. [CrossRef]

26. Su, B.; Shao, H.; Li, N.; Chen, X.; Cai, Z.; Chen, X. A sensitive bisphenol A voltammetric sensor relying on AuPd nanoparticles/graphene composites modified glassy carbon electrode. Talanta 2017, 166, 126-132. [CrossRef]

27. Fageria, P.; Uppala, S.; Nazir, R.; Gangopadhyay, S.; Chang, C.H.; Basu, M.; Pande, S. Synthesis of Monometallic ( $\mathrm{Au}$ and $\mathrm{Pd}$ ) and Bimetallic (AuPd) Nanoparticles Using Carbon Nitride $\left(\mathrm{C}_{3} \mathrm{~N}_{4}\right)$ Quantum Dots via the Photochemical Route for Nitrophenol Reduction. Langmuir 2016, 32, 10054-10064. [CrossRef]

28. Yang, X.; Pachfule, P.; Chen, Y.; Tsumori, N.; Xu, Q. Highly efficient hydrogen generation from formic acid using a reduced graphene oxide-supported AuPd nanoparticle catalyst. Chem. Commun. 2016, 52, 4171-4174. [CrossRef]

29. Luo, S.; Zhou, W.; Xie, A.; Wu, F.; Yao, C.; Li, X.; et al. Effect of $\mathrm{MnO}_{2}$ polymorphs structure on the selective catalytic reduction of $\mathrm{NOx}$ with $\mathrm{NH}_{3}$ over $\mathrm{TiO}_{2}-$ Palygorskite. Chem. Eng. J. 2016, 286, 291-299. [CrossRef]

30. Lu, Z.; Hao, Z.; Wang, J.; Chen, L. Efficient removal of europium from aqueous solutions using attapulgite-iron oxide magnetic composites. J. Ind. Eng. Chem. 2016, 34, 374-381. [CrossRef]

31. Bulut, A.; Yurderi, M.; Karatas, Y.; Zahmakiran, M.; Kivrak, H.; Gulcan, M.; Kaya, M. Pd-MnO $x$ nanoparticles dispersed on amine-grafted silica: highly efficient nano-catalyst for hydrogen production from additive-free dehydrogenation of formic acid under mild conditions. Appl. Catal. B Environ. 2015, 164, 324-333. [CrossRef]

32. Sahoo, A.; Tripathy, S.K.; Dehury, N.; Patra, S. A porous trimetallic Au@Pd@Ru nanoparticle system: Synthesis, characterisation and efficient dye degradation and removal. J. Mater. Chem. A 2015, 3, 19376-19383. [CrossRef]

33. Ma, J.; Zhu, C.; Lu, J.; Liu, H.; Huang, L.; Chen, T.; Chen, D. Catalytic degradation of gaseous benzene by using $\mathrm{TiO}_{2}$ /goethite immobilized on palygorskite: Preparation, characterization and mechanism. Solid. State Sci. 2015, 49, 1-9. [CrossRef]

34. Xu, C.; Liu, Y.; Hao, Q.; Duan, H. Nanoporous PdNi alloys as highly active and methanol-tolerant electrocatalysts towards oxygen reduction reaction. J. Mater. Chem. A 2013, 1, 13542-13548. [CrossRef]

35. Zhang, Z.K.; Guo, D.Z.; Xing, Y.J.; Zhang, G.M. Fabrication of open-ended $\mathrm{TiO}_{2}$ nanotube arrays by anodizing a thermally evaporated Ti/Au bilayer film. Appl. Surf. Sci. 2011, 257, 4139-4143. [CrossRef]

36. Qin, Y.H.; Li, Y.; Lv, R.L.; Wang, T.L.; Wang, W.G.; Wang, C.W. Pd-Au/C catalysts with different alloying degrees for ethanol oxidation in alkaline media. Electrochim. Acta 2014, 144, 50-55. [CrossRef]

37. Han, C.; Wu, L.; Ge, L.; Li, Y.; Zhao, Z. AuPd bimetallic nanoparticles decorated graphitic carbon nitride for highly efficient reduction of water to $\mathrm{H}_{2}$ under visible light irradiation. Carbon 2015, 92, 31-34. [CrossRef]

38. Xu, L.; Yao, F.; Luo, J.; Wan, C.; Ye, M.; Cui, P.; An, Y. Facile synthesis of amine-functionalized SBA-15-supported bimetallic Au-Pd nanoparticles as an efficient catalyst for hydrogen generation from formic acid. RSC Adv. 2017, 7, 4746-4752. [CrossRef]

39. Li, S.J.; Ping, Y.; Yan, J.M.; Wang, H.L.; Wu, M.; Jiang, Q. Facile synthesis of AgAuPd/graphene with high performance for hydrogen generation from formic acid. J. Mater. Chem. A 2015, 3, 14535-14538. [CrossRef]

40. Wang, Z.L.; Yan, J.M.; Wang, H.L.; Ping, Y.; Jiang, Q. Au@Pd core-shell nanoclusters growing on nitrogen-doped mildly reduced graphene oxide with enhanced catalytic performance for hydrogen generation from formic acid. J. Mater. Chem. A 2013, 1, 12721-12725. [CrossRef] 
41. Wu, S.; Yang, F.; Wang, H.; Chen, R.; Sun, P.C.; Chen, T.H. Mg(II)-assisted low temperature reduction of alloyed AuPd/C: an efficient catalyst for hydrogen generation from formic acid at room temperature. Chem. Commun. 2015, 51, 10887-10890. [CrossRef]

42. Zelekew, O.A.; Kuo, D.H. A two-oxide nanodiode system made of double-layered p-type $\mathrm{Ag}_{2} \mathrm{O} @$ n-type $\mathrm{TiO}_{2}$ for rapid reduction of 4-nitrophenol. Phys. Chem. Chem. Phys. 2016, 18, 4405-4414. [CrossRef]

43. Zhang, H.; Gao, S.; Shang, N.; Wang, C.; Wang, Z. Copper ferrite-graphene hybrid: A highly efficient magnetic catalyst for chemoselective reduction of nitroarenes. RSC. Adv. 2014, 4, 31328-31332. [CrossRef]

44. Liu, L.; Chen, R.; Liu, W.; Wu, J.; Gao, D. Catalytic reduction of 4-nitrophenol over Ni-Pd nanodimers supported on nitrogen-doped reduced graphene oxide. J. Hazard. Mater. 2016, 320, 96-104. [CrossRef]

45. Zhao, Y.; Wu, Z.; Wang, Y.; Yang, C.; Li, Y. Facile fabrication of polystyrene microsphere supported gold-palladium alloy nanoparticles with superior catalytic performance for the reduction of 4-nitrophenol in water. Colloid. Surf. A 2017, 529, 417-424. [CrossRef]

46. Srisombat, L.; Nonkumwong, J.; Suwannarat, K.; Kuntalue, B.; Ananta, S. Simple preparation Au/Pd Core/Shell nanoparticles for 4-Nitrophenol reduction. Colloid Surf. A 2016, 512, 17-25. [CrossRef]

47. Zhao, R.; Gong, M.; Zhu, H.; Chen, Y.; Tang, Y.; Lu, T. Seed-assisted synthesis of Pd@Au core-shell nanotetrapods and their optical and catalytic properties. Nanoscale 2014, 6, 9273-9278. [CrossRef]

48. Jiang, F.; Li, R.; Cai, J.; Xu, W.; Cao, A.; Chen, D.; et al. Ultrasmall Pd/Au bimetallic nanocrystals embedded in hydrogen-bonded supramolecular structures: Facile synthesis and catalytic activities in the reduction of 4-nitrophenol. J. Mater. Chem. A 2015, 3, 19433-19438. [CrossRef]

49. Chen, X.; Cai, Z.; Chen, X.; Oyama, M. AuPd bimetallic nanoparticles decorated on graphene nanosheets: their green synthesis, growth mechanism and high catalytic ability in 4-nitrophenol reduction. J. Mater. Chem. A 2014, 2, 5668-5674. [CrossRef]

(C) 2018 by the authors. Licensee MDPI, Basel, Switzerland. This article is an open access article distributed under the terms and conditions of the Creative Commons Attribution (CC BY) license (http:/ / creativecommons.org/licenses/by/4.0/). 